\title{
Investigating the Effect of Formulation on Phase Separation in Cornelian Cherry (cornus mass L) Concentrate Fortified with Whey
}

Behnaz Naderi ${ }^{1}$, Mehrnaz Aminifar ${ }^{2 *}$, Saba Belgheisi ${ }^{2}$

1- Dept. of Food Science \& Technology, Isfahan University of Technology (IUT), Isfahan, Iran.

2- Dept. of Food Science \& Technology, Faculty of Food Industry and Agriculture, Standard Research Institute (SRI), Karaj, Iran.

\section{A B S T R A C T}

Background and Objectives: Whey is a product of cheese production process that has more than half the nutrients of milk. Production of whey-based beverages, is one of the most efficient mechanisms for entering these products into the human food chain but its production is facing challenges. Protein sedimentation as a result of the thermal processing and the appealing sensory properties of the beverage are most important challenges.

Materials and Methods: Response surface methodology is effective method for formulating new products. In this study for formulating cornelian cherry whey-based beverage, Response Surface Methodology (RSM), engaging the Central Composite Rotatable Design (CCRD) was used. The ingredients range used for production beverage comprised of whey protein cornelian cherry juice concentrate 10-20 g, pectin 0.3-0.9 g and sugar 7.5-15 g in $100 \mathrm{~g}$ whey-based cornelian cherry juice beverage. To calculate phase separation percentage of samples at day 7 , the serum phase volume was determined and the value of it was divided to the total volume of juice. A group of seven trained judges were selected on the basis of triangle test for sensory evaluation of optimum sample. All evaluations used 9-point hedonic scale.

Results: Optimum sample with $13.5 \mathrm{w} / \mathrm{w} \%$, of concentrate, w/w $0.88 \%$ pectin, and w/w $14.48 \%$ sugar with w/w $19.78 \%$ phase separation was obtained by Response Surface Methodology, and the overall acceptability of it was 7.1.

Conclusions: This study attempts to remove the technical problem that inhibits the development of whey protein-containing cornelian cherry concentrate. Response Surface Methodology (RSM) was successfully used to improve the production of cornelian cherry whey-based beverage.

Keywords: Whey protein concentrate, Cornelian cherry concentrate, Pectin, Beverage, Response surface methodology

\section{Introduction}

Whey is produced during the production of cheese, Paneer, Chhana, Chakka, and Casein. Whey is a mixture of several commercially valuable proteins that are important in the food industry in terms of nutritional and biological factors (1). Whey compounds include $45-50 \%$ of total milk solids, $70 \%$ of milk sugar (lactose), $20 \%$ of milk proteins and70$90 \%$ of milk minerals and most importantly, almost all the water soluble vitamins originally present in milk (2).

Increased awareness of health issues leads to increased consumption of healthy foods, so the food industry specialists trying to produce products that in addition to sensory properties and good appearance also have healthy properties (3).

Juices are considered as an appropriate matrix for carrying and delivering whey proteins into the human 
diet. However, the poor sensory profile of whey protein beverages still remains a challenge to consumer acceptance. A lot of studies have been done on whey based fruit juice with various formulation to obtain an optimal mixture based on sensory acceptance (4).

Beucler et al. (2005) stated that sensitivity of whey to heat, is a fundamental feature of whey and whey proteins in the processing industry of whey and preparing the beverage of it (5). Whey proteins depending on the intensity of heat applied during the heating process, denature in the production of beverage. Pectin has a positive effect on thermal stability of whey proteins. To prevent protein coagulation during the thermal process of whey-based beverages and sediment of it during subsequent storage and to increase the apparent viscosity of the beverage, carbohydrates such as pectin are added to the beverage (6).

Hydrocolloids in acidified milk products prevent precipitation of proteins, divided in to two categories; absorbent and non-absorbent. Absorbent hydrocolloids stabilize protein by reducing electrostatic repulsion and reducing repulsion spatial distribution of atom. Non-absorbent hydrocolloids create stability of environment by increasing the viscosity of the continuous phase (7).

High methyl pectin is a common hydrocolloid used to prevent or reduce coalescence of proteins and preventing their sediment in the acidified milk beverages, that basically stabilize beverages through the mechanisms of spatial and electrostatic repulsion (8).

The formulation of whey protein beverages with good stability and optimal sensory properties is a cost and time-consuming process. Response surface methodology (RSM) reduces the number of tests required and provides a mathematical model for describing the effects of independent variables (9).

In the present study, the formulation of cornelian cherry juice supplemented with whey protein concentrate (WPC) is introduced. The aim of this study was to optimize the formulation of fruit juice beverages supplemented with WPC via an RSM approach in order to obtain products with pleasant sensory attributes and no sedimentation tendency.

\section{Materials and Methods}

Materials: High methyl pectin was purchased from Germany Danisco Company. Sucrose was purchased from a local market (Tehran, Iran). WPC containing $69.5 \%$ of protein was procured from Pegah, Tehran.

Cornelian cherry concentrate: Cornelian cherries (Cornus mas L.) were purchased from the local market in Karaj, Iran and the fruits were selected on the basis of their appearance, and after washing and cleaning, they were placed in a water bath for 24 hours. After that, the juice was taken by pressing and the original brix ( $7^{\circ}$ brix ) was brought to the $42^{\circ}$ brix by a programmable microwave (Butane MR-1, Iran, using a maximum output of $900 \mathrm{~W}$ at $2450 \mathrm{MHz})(10$. 11).

Optimization studies for production of beverage: Level variables used in the formulation were determined according to the phase separation percentage of the samples. Raw materials based on table 1 were mixed together, and the final volume was $100 \mathrm{ml}$. Beverages were pasteurized for 20 seconds at $72{ }^{\circ} \mathrm{C}$. For sensory evaluation, sample were stored for $24 \mathrm{~h}$ at $4{ }^{\circ} \mathrm{C}$ and to measure phase separation, were kept for a week at $4^{\circ} \mathrm{C}$ in the refrigerator. To calculate phase separation percentage of samples at day 7 , the serum phase volume was determined and the value of it was divided into the total volume of juice (12).

Table 1. The Central Composite Rotatable Design for cornelian cherry juice Concentrate, Sugar and pectin

\begin{tabular}{cccc}
\hline Formulation & \multicolumn{3}{c}{ component } \\
\cline { 2 - 4 } & $\begin{array}{c}\text { cornelian cherry } \\
\text { juice concentrate }\end{array}$ & sugar & pectin \\
\hline 1 & 10 & 7.5 & 0.3 \\
2 & 20 & 7.5 & 0.3 \\
3 & 10 & 15 & 0.3 \\
4 & 20 & 15 & 0.3 \\
5 & 10 & 7.5 & 0.9 \\
6 & 20 & 7.5 & 0.9 \\
7 & 10 & 15 & 0.9 \\
8 & 20 & 15 & 0.9 \\
9 & 6.59 & 11.25 & 0.6 \\
10 & 23.41 & 11.25 & 0.6 \\
11 & 15 & 4.94 & 0.6 \\
12 & 15 & 17.56 & 0.6 \\
13 & 15 & 11.25 & 0.1 \\
14 & 15 & 11.25 & 1.1 \\
15 & 15 & 11.25 & 0.6 \\
16 & 15 & 11.25 & 0.6 \\
17 & 15 & 11.25 & 0.6 \\
18 & 15 & 11.25 & 0.6 \\
19 & 15 & 11.25 & 0.6 \\
20 & 15 & 11.25 & 0.6 \\
\hline
\end{tabular}

Sensory evaluation: Sensory evaluation was performed by seven trained judges. A simple acceptance test for the whey beverage was conducted 
using a 9- point hedonic rating scale. Scale ratings were converted to numerical scores: 9, like extremely; 8 , like very much; 7 , like moderately; 6 , like slightly; 5 , neither like nor dislike; 4 , dislike slightly; 3 , dislike moderately; 2 , dislike very much; 1 , dislike extremely (13).

Statistical analysis: ANOVA obtained from RSM software was used for optimization studies. The variables included WPC, sugar and pectin. Two sample $\mathrm{T}$-test was performed with the predicted and observed three replicates values of optimized formulation for calculating the statistical significance $(\mathrm{P}<0.05)$.

\section{Results}

As a result of regression and analysis of variance (ANOVA) for response, variables showed that the effect of cornelian cherry juice concentrate, sugar, pectin and interaction between cornelian cherry juice concentrate-sugar and concentrate- pectin is significant on phase separation percentage at the level of 0.05(Table 2).

The non-significant lack of fit test showed that the model is properly appropriate for determining the phase separation percentage of cornelian cherry whey-based beverages prepared from any combination of the variables within the range evaluated. The adequate precision, which measures the signal-to-noise ratio, is more than four for all the responses, which is highly desirable (Table 2).
Table 2. Regression coefficients and ANOVA of fitted quadratic model of cornelian cherry whey-based beverages

\begin{tabular}{ccc}
\hline F value & $p$-value prob $>F$ & Partial coefficients \\
\hline 50.59 & $<0.0001$ & model \\
52.24 & $<0.0001$ & A-concentrate \\
20.98 & 0.0010 & B-sugar \\
273.31 & $<0.0001$ & C-pectin \\
8.99 & 0.0134 & AB \\
5.06 & 0.0483 & $\mathrm{AC}$ \\
4.25 & 0.0662 & $\mathrm{BC}$ \\
82.18 & $<0.0001$ & $\mathrm{~A}^{2}$ \\
2.54 & 0.1419 & $\mathrm{~B}^{2}$ \\
13.91 & 0.0039 & $\mathrm{C}^{2}$ \\
1.01 & $0.4960(\mathrm{NS})$ & Lack of Fit \\
0.9785 & - & $\mathrm{R}^{2}$ \\
22.260 & - & Adeq. Press \\
\hline
\end{tabular}

Response surface plots for interaction effects of concentrate and sugar on phase separation (Table 3) percentage of beverages is shown in Figure 1(a). In all levels of sugar, by increasing the concentrate, phase separation percentage increased. As shown in table 3, by increasing the concentration, $\mathrm{pH}$ decreases, and becomes closer to isoelectric $\mathrm{pH}$ of whey proteins, causing a precipitate. The results also showed that interaction between sugar and concentrate on phase separation percentage is significant at 0.05 level. So that at low levels of concentrate $(10 \mathrm{~g})$ with reduced sugar phase separation percentage, the change was not significant. Although, at high levels of concentrates (20 grams) by reducing sugar, the amount of water and also separation of two phases will increase.

Table 3. $\mathrm{pH}$ and phase separation of cornelian cherry whey based beverages

\begin{tabular}{cccccc}
\hline Formulation & \multicolumn{3}{c}{ component } & pH & Phase separation (\%) \\
\cline { 2 - 4 } & concentrate & sugar & pectin & & \\
\hline 1 & 10 & 7.5 & 68 & 0.3 & 3.5 \\
2 & 20 & 7.5 & 80 & 0.3 & 3.5 \\
3 & 10 & 15 & 68 & 0.3 & 3.4 \\
4 & 20 & 15 & 70 & 0.3 & 3.5 \\
5 & 10 & 7.5 & 30 & 0.9 & 3.6 \\
6 & 20 & 7.5 & 60 & 0.9 & 3.5 \\
7 & 10 & 15 & 25 & 0.9 & 3.6 \\
8 & 20 & 15 & 33 & 0.6 & 3.9 \\
9 & 6.59 & 11.25 & 48 & 0.6 & 3.4 \\
10 & 23.41 & 11.25 & 77 & 0.6 & 3.7 \\
11 & 15 & 4.94 & 48 & 0.6 & 3.7 \\
12 & 15 & 17.56 & 35 & 0.1 & 3.7 \\
13 & 15 & 11.25 & 75 & 1.1 & 3.7 \\
14 & 15 & 11.25 & 20 & 0.6 & 3.7 \\
16 & 15 & 11.25 & 35 & 0.6 & 3.7 \\
17 & 15 & 11.25 & 45 & 0.6 & 3.7 \\
19 & 15 & 11.25 & 40 & 0.6 & 3.7 \\
& 15 & 11.25 & 40 & 0.6 & 3.7 \\
\hline
\end{tabular}



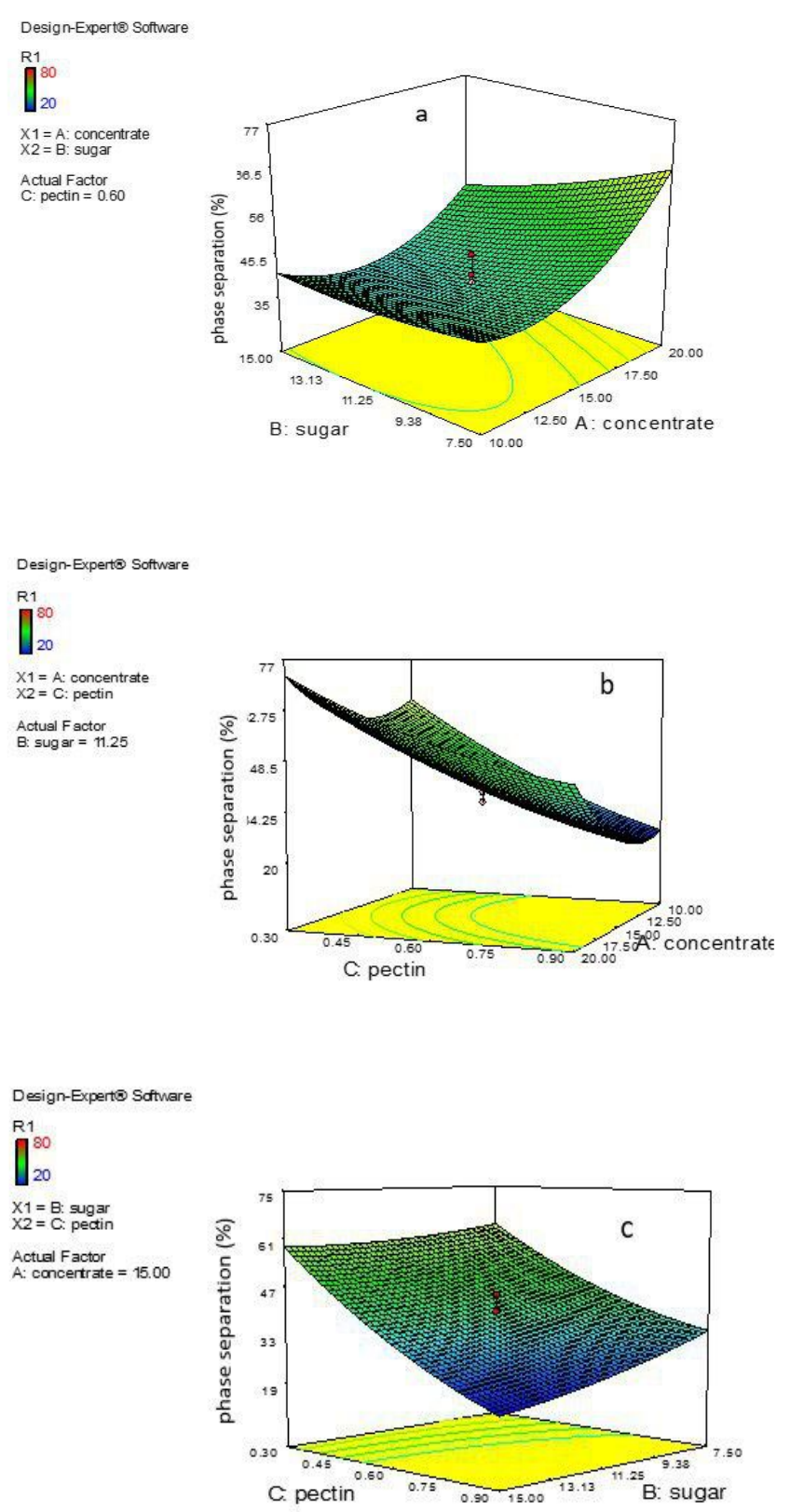

Figure 1. Response surface plots for interaction effects of cornelian cherry juice concentrate, sugar and pectin on phase separation percentage of cornelian cherry wheybased beverages. (a) Interaction effects of cornelian cherry juice concentrate and sugar on phase separation percentage of beverages (b) Interaction effects of cornelian cherry juice concentrate and pectin on phase separation percentage of beverages (c) Interaction effects of pectin and sugar on phase separation percentage of beverages

Figure 1(b) shows the effect of interaction between concentrate and pectin on phase separation percentage. Studies showed that in all the samples, in lower concentrations of pectin the phase separation is seen. The upper phase of beverages was clear and lower phase was turbid, the turbidity is indicated of protein aggregation. Analysis of variance (ANOVA) showed that the interaction between concentrate Pectin on the phase separation percentage in 0.05 level is significant (Table2). The results of surface response showed that percentage of phase separation in high levels of cornelian cherry juice concentrate $(20 \mathrm{~g})$ is more compared to a sample with less cornelian cherry juice concentrate $(10 \mathrm{~g})$. It indicates that a $\mathrm{pH}$ of samples on phase separation percentage is effective.

Figure 1 (c) also shows simultaneous effect of interaction of sugar and pectin on the phase separation percentage. As a result of regression and analysis of variance (ANOVA) for response, variables showed that the interaction effect of sugar-pectin on the percentage of phase separation is not significant. Thus, as a general trend, at all levels of sugar, with increasing concentrations of pectin, phase separation percentage decreases.

The following response surface equation was developed to predict the change in separation percentage due to different levels of variable:

phase separation $(\%)=+140.05574-8.13554 \times$ cornelian cherry juice concentrate $+0.88397 \times$ sugar $-108.17460 \times$ pectin $0.21333 \times$ cornelian cherry juice concentrate $\times$ sugar $+2.00000 \times$ cornelian cherry juice concentrate $\times$ pectin $+0.36038 \times$ cornelian cherry juice concentrate ${ }^{2}+0.11270 \times$ sugar $^{2}+41.17919 \times$ pectin $^{2}$

Optimized solution for the formulation and its validation: Phase separation percentage was considered as the optimization criterion in this study. Cornelian cherry juice concentrate, sugar and pectin were kept within the range and responses as phase separation percentage were aimed at a minimum during optimization process. A sample with $13.5 \mathrm{w} / \mathrm{w}$ $\%$, of cornelian cherry juice concentrate $0.88 \mathrm{w} / \mathrm{w} \%$ $.14 .48 \mathrm{w} / \mathrm{w} \%$ sugar and pectin with desirability 1 and 19.78 percentage of phase separation as the optimum sample was obtained. The percentage of phase separation of beverages measured in this study is compatible with predictions of models at a $95 \%$ confidence interval (using a t-test) thus validating the suggested solution from RSM to be the most preferred formulation(Table 4). 
Table 4. Verification of the predicted and observed sensory scores of cornelian cherry whey-based beverages

\begin{tabular}{cccc}
\hline \multirow{2}{*}{ Response } & \multicolumn{3}{c}{ cornelian cherry whey-based beverages } \\
\cline { 2 - 4 } & Predicted value & Observed value & $\mathrm{t}_{0.01}$ value \\
\hline $\begin{array}{c}\text { Phase separation } \\
(\%)\end{array}$ & 19.4955 & $19.16 \pm 0.17$ & $-1.94^{\mathrm{ns}}$ \\
\hline
\end{tabular}

ns: not significant $(\mathrm{P}<0.01)$

Sensory evaluation: The sensory evaluations of optimized beverages $(13.5 \%$, of cornelian cherry juice concentrate, $0.88 \%$ pectin and $14.48 \%$ sugar) were performed by a panel of 7 trained judges using a 9point hedonic scale. The overall acceptability of beverage was 7.1 which is the rating very good and considerable.

\section{Disc ussion}

Cornelian cherry whey-based beverage is an acidified drink, separation of phases during its production and storage is a major problem within its production. phase separation is caused by protein precipitation in beverage due to various factors such as heat and low $\mathrm{pH}$ process. In low $\mathrm{pH}$, some of the phenomena such as the reduction of zeta potential and the irreversible accumulation of three-dimensional network of protein happens (8). Whey protein denaturation leads to the formation of small aggregated oligomers that form either spherical or linear aggregates based on solution conditions. These aggregates may remain soluble, or form larger aggregates that precipitate or form a threedimensional gel network. Steps are dependent on a number of conditions, including $\mathrm{pH}$, protein concentration, ionic strength, heating rate and temperature. $(14,15)$.

Research shows that in acidic drinks, pectin chains through units of charged molecule due to electrostatic interactions which are $\mathrm{pH}$-dependent, absorbed on the surface of protein, and uncharged parts as rings or tail-like entered into the solution cause stability of these types of drinks $(16,17)$.

Pectin, in the $\mathrm{pH}$ range between 3.5 and 4.6, protect and stabilize the proteins during thermal processing (18). When $\mathrm{pH}$ of acidic milk drink is reduced and close to $\mathrm{pk}_{\mathrm{a}}$ pectin (3.5), probably tend to absorb of pectin decreases. So, Pectin unabsorbed through the mechanism of depletion flocculation cause instability of system(17).
Solution $\mathrm{pH}$ is one of the major factors determining the thermal and long-term stability of whey protein beverages. Etzel(2004) showed that at $\mathrm{pH} 3.5$, a model whey protein isolate beverage remained clear after hot fill treatment while at $\mathrm{pH} 4.0$ the beverage became turbid (19).

This suggests that electrostatic repulsion is strong enough at $\mathrm{pH} 3.5$ to limit protein-protein interactions. Between $\mathrm{pH} 3.5-4.0$ the beverage transitions from clear to turbid. It is important to note that the proteins still undergo denaturation in this $\mathrm{pH}$ range, but the electrostatic repulsion limits protein-protein interactions or aggregation (20). It addition to stronger electrostatic repulsion, disulfide exchange reactions does not occur in the low $\mathrm{pH}$ range so disulfide-mediated aggregation would be reduced, which would likely result in decreased particle size $(21,22)$., It seems that the use of hydrocolloids on the one hand because of the ability to communicate between protein and water and on the other hand by increasing the viscosity, can be reduce the phase separation and volatile flavor and aroma. In fact, the hydrocolloids by trapping taste compounds prevent gradual separation at the time of storage $(23,24)$. Also Mathur and Shahani (1979) conducted research in which lactose in whey is added to foods, as a vehicle for color and (25).

\section{Conclusion}

The purpose of this study was to formulate a wheybased beverage containing of cornelian cherry by employing Response Surface Methodology (RSM) engaging the Central Composite Rotatable Design (CCRD). Optimal formulation Prepared with cornelian cherry concentrate $(13.5 \%$, of concentrate, $0.88 \%$ pectin and $14.48 \%$ sugar) has an acceptable stability during the storage, also in terms of flavor, color and overall acceptability were in the acceptable range.

\section{Financial disclosure}

The authors declared no financial interest.

\section{Funding/Support}

There is no funding.

\section{References}

1. Smithers GW, Ballard FJ, Copeland AD, De Silva KJ, Dionysius DA, Francis GL. Symposium: advances in dairy foods processing and engineering. Journal of Dairy Science .1996; 79:1454-9. 
2. Boghani AH, Raheem A, Hashmi SI. Development and storage studies of blended papaya-aloe vera ready to serve (RTS) beverage. Journal of Food Processing and Technology.2012; 3: 1000185.

3. Herman CP, Polivy J. Restrained eating. In A. Stunkard (Ed.), Obesity Philadelphia, PA: Saunders .1980; 208225.

4. Djuri M, Caric M, Milanovic S, Tekic M, Panic M. Development of whey-based beverages. European Food Research and Technology.2004; 219: 321-328.

5. Beucler J, Drake Maryanne and Foegeding E,Allen. Design of a Beverage from Whey Permeate . Journal of Food Science. 2005; 70: 285-277.

6. Asha S, Nithisha K, Bharath Kumar R, Ravi Kumar V.Deciphering the antimicrobial potential of cinnamon zeylanicum bark. International Journal of Pharm Tech Research . 2014; 6: 1226-1235.

7. Azarikia F, Abbasi S. On the stabilization mechanism of Doogh (Iranian yoghurt drink) by gum tragacanth. Food Hydrocolloids. 2009; 50: 87-94.

8. Janhojo T, Frost MB, Ipsen R. Sensory and rheological characterization of acidified milk drinks. Food Hydrocolloids. 2008; 22: 798-806.

9. Madadlou A, Emam-Djomeh Z, Mousavi M E, Ehsani M, Javanmard M, Sheehan D. Response surface optimization of an artificial neural network for predicting the size of re-assembled casein micelles. Computers and Electronics in Agriculture. 2009a; 68: 216-221.

10. Koksoy A, KilicM. Use of hydrocolloids in textural stabilization of a yoghurt drink, ayran. Food Hydrocolloids. 2004; 18: 593-600.

11. Naderi B ,Maghsoudlou Y, Aminifar M , Ghorbani M, Rashidi L. Comparison of Microwave with Conventional Heating on Phytochemical Compounds of Cornelian Cherry (Cornus mas L.) Concentrate. Journal of Agricultural Science and Technology. 2016; 18: 11971208 .

12. Naderi B, Maghsoudlou Y, Aminifar M, Ghorbani M, Rashidi L. Investigation on the Changes in Color Parameters and Turbidity of Cornelian Cherry (cornus mass L) Produced by Microwave and Conventional Heating. Nutrition and Food Sciences Research; 2015; $39-46$

13. Amerine MA, Pongborn RM, Roessler EB. Principles of sensory evaluation of food. Academic Press, Inc., 1965; New York.
14. Ryan KN, Zhong Q, Foegeding EA. Use of whey protein soluble aggregates for thermal stability-a hypothesis paper. Journal of Food Science. 2013; 78: 1105-1115.

15. Nicolai T, Britten M, Schmitt C. $\beta$-Lactoglobulin and WPI aggregates: formation, structure and applications. Food Hydrocolloids. 2011; 25:1945-1962.

16. Cucheval A, Al-Ghobashy M. A, Hemar Y, Otter D, Williams MAK. Direct measurements of interfacial interactions between pectin and $\mathrm{j}$-casein and implications for the stabilisation of calcium-free casein micelle mimics. Journal of Colloid and Interface Science.2009; 338: 450-462.

17. Maroziene A, De Kruif CG. Interaction of pectin and casein micelles. Food Hydrocolloids.2000; 14: 391-394.

18. Rittmanic SUS. Whey Protein in Ready-to-Drink Beverages. Nutritional Food and Beverage Development, Arizona, USA. Edited by Kimberlee J. Burrington. Dairy Ingredient Applications Laboratory, Wisconsin Center for Dairy Research, University of Wisconsin, USA

19. Etzel M R . Manufacture and use of dairy protein fractions. Journal of Nutrition. 2004; 34 (4): 996S $1002 S$.

20. Bernal V, Jelen P. Thermal stability of whey proteins-A calorimetric study. Journal of Dairy Science. 1985; 68:2847-2852.

21. Harwalkar V. Kinetics of thermal denaturation of âlactoglobulin at $\mathrm{pH}$ 2.5. Journal of Dairy Science.1980a; 63 (7): 1052-1057.

22. Harwalkar V. Measurement of thermal denaturation of âlactoglobulin at $\mathrm{pH} 2.5$. Journal of Dairy Science. 1980b; 63: 1043-1051.

23. Gallardo-Escamilla FJ, Kelly AL, Delahunty CM. Mouthfeel and flavor of fermented whey with added hydrocolloids. International Dairy Journal. 2007; 17(4): 308-315.

24. Lucey JA, Tamehana M, Singh H, Munro PA. Stability of model acid milk beverage: effect of pectin concentration, storage temperature and milk heat treatment. Journal of Texture Studies.1999; 30 (3): 305-318.

25. Mathur BN, Shahani KM. Use of Total Whey Constituents for Human Food. Journal of Dairy Science. 1979; 62: 99-105. 